\title{
Efektifitas Pestisida Biologis Bacillus Cereus dan Bacillus Megaterium. sebagai Pengendali Spodoptera litura Fabr (Lepidoptera: Noctuidae)
}

\section{The effectiveness of Biological Pesticides Bacillus cereus and Bacillus megaterium. As Controller of Spodoptera litura Fabr. (Lepidoptera: Noctuidae)}

\author{
I Made Indra Agastya ${ }^{1 *}$, Aminudin Afandhi ${ }^{2}$, Luqman Qurata Aini' ${ }^{2}$. \\ ${ }^{1)}$ PS Agroteknologi Fakultas Pertanian Universitas Tribhuwana Tungga Dewi \\ Jl. Telaga warna Tlogomas, 65144 Malang Jawa Timur \\ 2) Jurusan Hama dan Penyakit Tumbuhan Fakultas Pertanian Universitas Brawijaya \\ *Email.indra.agastya@unitri.ac.id
}

\begin{abstract}
This research was conducted in vitro in the laboratory. Studies conducted in the Laboratory of Bacteriology Department of Plant Pests and Diseases of the Faculty of Agriculture, University of Brawijaya, on the effectiveness of the bacteria Bacillus cereus and Bacillus megaterium as biological pesticides controlling Spodoptera litura. The objective of this study was to determine the effectiveness of the bacteria Bacillus $\mathrm{sp}$ as biological control. Effectiveness pesticide was measured by testing the incubation period and mortality in larvae of $S$. litura instar 3. This study used a completely randomized design (CRD), conducted observations every 6 hours until the larvae dead. The results showed that the percentage of mortality of $S$. litura reached $94.66 \%$ compared to the control, while the incubation time of the bacteria B. cereus cause disease until 29.84 hours. B. cereus and B. megaterium have the ability to incubate third instar larvae of $S$. litura up to 29.84 hours and caused the death of larvae up to $94.66 \%$.
\end{abstract}

Keywords: Biological pesticides, Bacillus cereus, Bacillus megaterium, entomopatogen, Spodoptera litura

Diterima : 27 Januari 2017, Disetujui : 22 Juli 2017

\section{PENDAHULUAN}

Serangga Spodoptera litura merupakan hama polyfag yang banyak menyebabkan kerugian pada tanaman budidaya, kususnya kedelai. Serangan S. litura pada tanaman kedelai di Desa Setanggor Kecamatan Praya Barat tahun 2013 menyebabkan gagal panen. Serangan S. litura secara seporadis mampu menghabiskan tanaman kedelai seluas 1,5 Ha dalam waktu semalam (BP2TP NTB, 2014).

Ledakan serangan $S$. litura dapat disebabkan oleh terganggunya ekosistem pertanian yang diakibatkan penggunaan pestisida yang tidak tepat. Penggunaan pestisida kimia yang berlebihan dapat menyebabkan resurgensi pada hama sekunder, resistensi hama sasaran, dan musnahnya musuh alami (Untung, 1993). Musuh alami dari S. litura diantaranya patogen serangga, parasitoid dan predator (Tanada \& Kaya, 1993). Patogen serangga banyak dimanfaatkan sebagai pengendali serangga hama yang efektif dan ramah lingkungan. (Mandal et al, 2003). Bakteri Bacillus sp merupakan patogen serangga memiliki kelebihan dapat bereproduksi yang cepat, siklus hidup singkat dan spesifik terhadap hama sasaran (Rohani, 1991).

Tujuan dari penelitian ini adalah untuk mengetahui efektifitas bakteri Bacillus cereus dan Bacillus megaterium yang dilakukan dengan pengujian secara invitro sebagai pestisida biologis terhadap S. litura . 


\section{METODE PENELITIAN}

Penelitian dilaksanakan di Laboraturium Bakteriologi, Jurusan Hama dan Penyakit tumbuhan, Fakultas Pertanian, Universitas Brawijaya. Penelitian dilaksanakan pada Bulan Mei 2014.

Bahan penelitian meliputi biakan bakteri patogen serangga Bacillus cereus dan Bacillus megaterium yang diperoleh dari lapisan rizosfer tanaman kedelai pada lahan kering di desa Stanggor, Kecamatan Praya barat Kabupaten Lombok Tengah. Serangga uji S. litura instar tiga yang diperoleh dari Balai Penelitian Tanaman Pemanis dan Serat Malang. Alat-alat yang digunakan dalam penelitian adalah Laminar Air Flow Cabinet, cawan petri, Erlenmeyer, gelas ukur, mikroskop, gelas obyek, gelas penutup, Autoclave, Specrofotometer, tabung reaksi, toples $1 \mathrm{~kg}$, Kain kasa, timbangan Triple Beam, Termohigrometer, lampu bunsen, penggaris, Jarum preparat, alat tulis menulis.

Rancangan percobaan yang digunakan adalah rancangan acak lengkap (RAL), isolat B.cereus dan $B$. megaterium diencerkan sampai $10^{-7}$ per $\mathrm{ml}$, kemudian disemprotkan pada pakan larva $S$. litura sebanyak $2 \mathrm{ml}$ setiap unit percobaan, dimana pada setiap unit percobaaan terdapat 25 ekor larva dan setiap unit percobaan diulang sebanyak 3 kali. Pengamatan dilakukan pada saat perlakuan dan setiap 6 jam setelah perlakuan hingga 1 minggu, dengan cara melihat gejala yang timbul hingga kematian larva $S$. litura.

Pengamatan Masa Inkubasidilakukan saat pengaplikasian hingga gejala penyakit tampak. Pengamatan dilakukan setiap hari sampai seluruh larva terinfeksi. Gejala yang ditimbulkani dapat terlihat dengan perubahan yang terjadi pada tubuh larva. Perubahan yang terjadi terlihat adanya perubahan aktifitas, pembengkakan tubuh, gerakan lamban, nafsu makan berkurang, diare, dan tidak mau makan. Perhitungan masa inkubasi dapat dihitung dengan rumus (Busvine, 1971).

$$
I=\frac{\sum(k x h)}{K}
$$

I = Rata-rata masa inkubasi (hari)

Keterangan : $\quad \mathrm{k}=$ Jumlah larva yang terinfeksi oleh bakteri tiap hari pengamatan

$\mathrm{h}=$ Hari pengamatan

$\mathrm{K}=$ Jumlah larva yang terinkubasi oleh bakteri

Pengamatan Mortalitas S. Litura pertama dilakukan setiap hari setelah aplikasi sampai seluruh larva mati. dengan menggunakan rumus (Busvine, 1971) sebagai berikut.

$$
\mathrm{M}=\frac{A}{B} \times 100 \%
$$

Keterangan:

$$
\begin{aligned}
& M=\text { Mortalitas } \\
& A=\text { Jumlah larva mati oleh bakteri } \\
& B=\text { Jumlah larva yang diperlakukan }
\end{aligned}
$$

\section{HASIL DAN PEMBAHASAN}

Masa Inkubasi Isolat bakteri B. cereus dan B. megaterium dalam menginfeksi S. Litura membutuhkan waktu yang bervariasi dari 29.84 hingga 22.52 jam, Gambar 1 menunjukkan bakteri B. cereus lebih patogenik dari B. megaterium. Perbedaan tersebut disebabkan toksisitas dari patogen berbeda dalam menginfeksi larva S. litura dan kemampuan bakteri untuk memproduksi toksin berbeda setelah berada didalam tubuh serangga. 


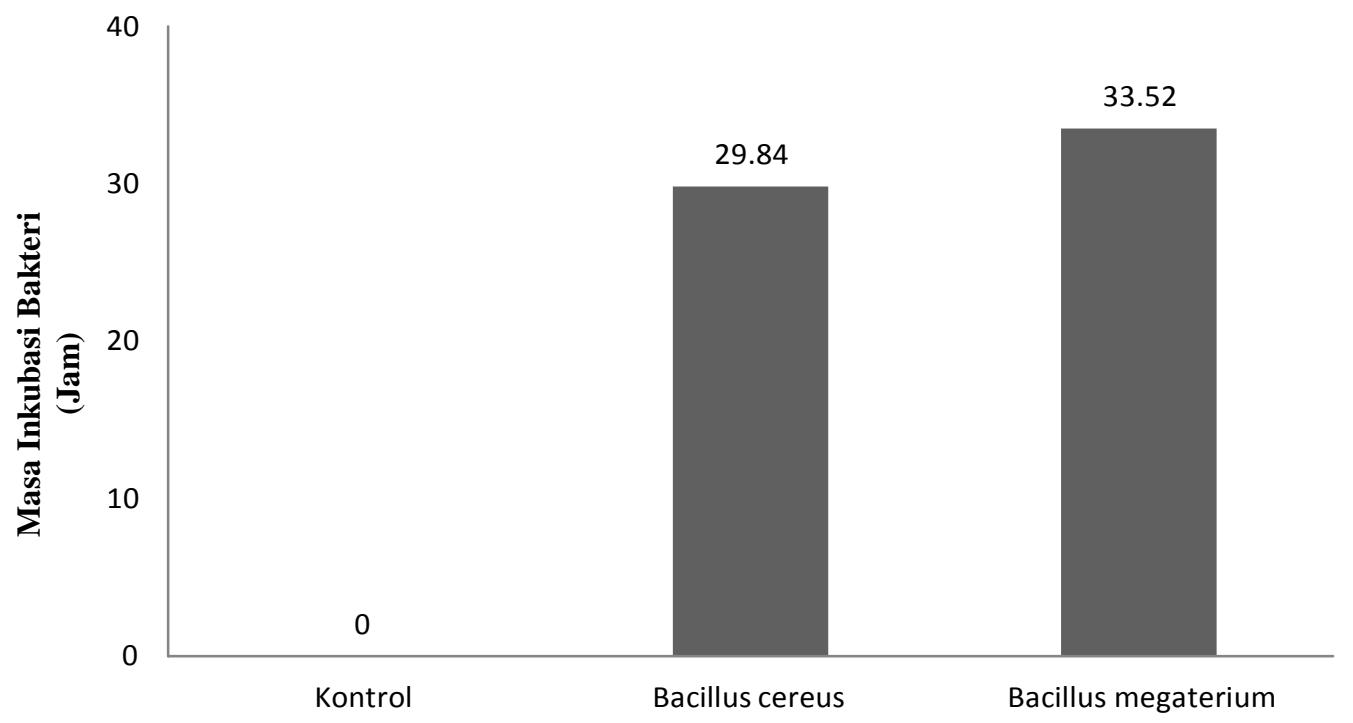

Gambar 1. Masa inkubasi bakteri Patogen serangga pada S. Litura

B. cereus dan B. megaterium merupakan agen yang mempunyai daya toksisitas terhadap berbagai serangga karena organisme ini menghasilkan toksin selama sporulasi. Bahan aktif yang mempunyai aktivitas larvisidal ini adalah $\delta$-endotoksin (Agaisse \& Lereclus, 1995). Selain itu imunitas dari larva juga mempengaruhi toksisitas bakteri.

Persentase Mortalitas larva pada 162 jam aplikasi bakteri B. cereus dan B. meganterium dengan kepadatan populasi $3.32 \times 10^{9} \mathrm{CFU} / \mathrm{ml}$, menyebabkan mortalitas larva berkisar hingga $89.33 \%-94.66 \%$ ditunjukkan pada Gambar 2. Isolat B. meganterium memiliki persentase lebih rendah membunuh larva S. litura dari $B$. cereus hal ini diduga disebabkan jenis toksin dari bakteri patogen serangga berbeda.

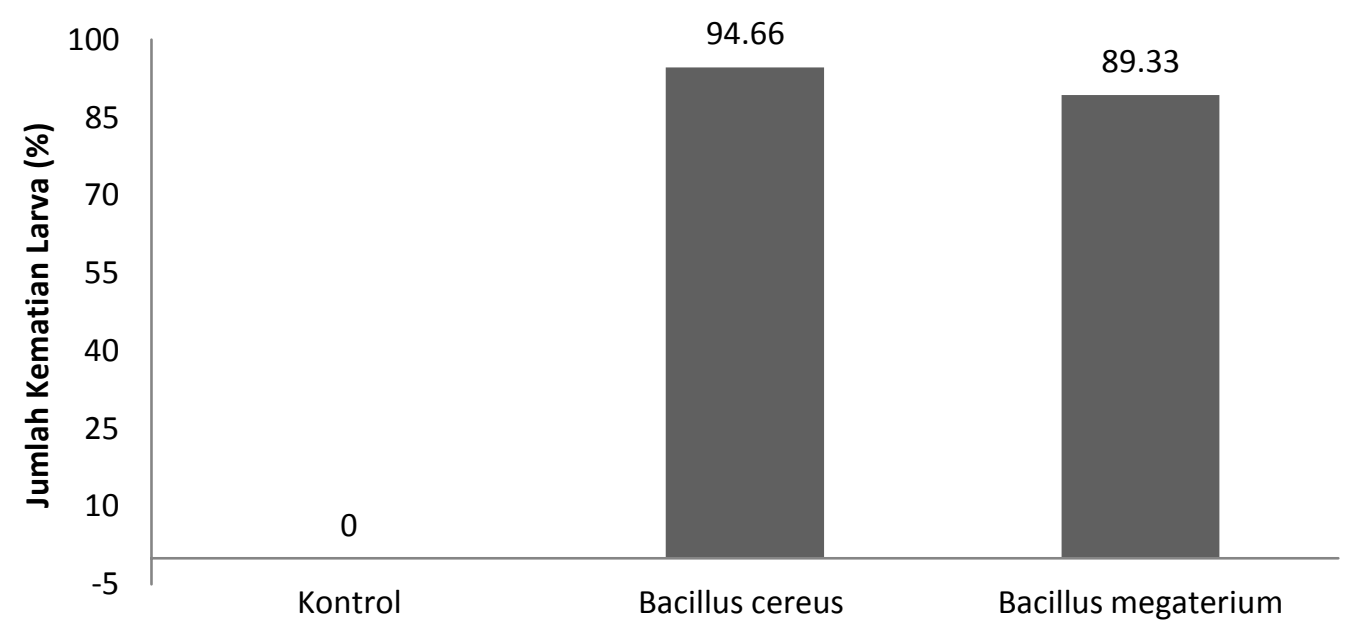

Gambar 2. Jumlah kematian larva S. litura oleh bakteri patogen serangga

Bakteri pathogen serangga mengeluarkan aktivitas hemolisin yang menjadi toksin pada serangga. Hemolisin bakteri berfungsi sebagai eksotoksin, yang mengakibatkan pecahnya sel yang menyebabkan paralisis pada serangga, daya kerja $\delta$-endotoksin pada Bacillus sp terletak pada kristal protein. Faktor penentu keefektifan $\delta$-endotoksin antara lain, adalah strain bakteri, daya larut kristal protein dalam saluran makanan, serta kepekaan serangga terhadap toksin (Lee et al, 1999).

B. cereus merupakan bakteri tular tanah tanah yang gram positif, aerob fakultatif dan dapat membentuk spora (endospora) berukuran panjang sel $3 \mu \mathrm{m}$ dan diameter $1.2 \mu \mathrm{m}$. Spora B. cereus lebih tahan pada panas kering dari pada panas lembab dan dapat bertahan lama pada produk yang kering. Selnya berbentuk batang besar (bacillus). B. cereus memiliki kemampuan menghancurkan sel darah merah yang bersifat hymolitik 
dengan jenis toksin beta hemotoksin. Margulis (1998) Melaporkan B. cereus adalah juga ditemukan dalam mikroflora usus invertebrata, B. cereus masuk kedalam pencernaan Arthopoda melalui pakan yang dikonsumsi. Tahap ini B. cereus, juga dikenal sebagai tahap Arthromitus, meliputi pelekatan dari endospora yang dikeluarkan oleh sel $B$. cereus dan diikuti dengan pertumbuhan filament serta bergerak motil pada jaringan epitel usus Arthopoda.

B. megaterium merupakan bakteri endofit dan merupakan agen hayati yang sangat potensial. De vos (2009) melaporkan beberapa strain B. megaterium dapat memfiksasi nitrogen. Metabolisme B. megaterium didalam lingkungan tanah menjadi aktif ketika substrat yang cocok untuk pertumbuhan tersedia. Pembentukan spora terjadi ketika kondisi lingkungan dan inang tidak mendukung (Kenneth, 2012).

\section{KESIMPULAN}

Berdasarkan hasil penelitian tersebut dapat disimpulkan bahwa Bakteri B. meganterium dan B. cereus efektif digunakan sebagai pestisida biologis untuk mengendalikan $S$. litura dengan masa inkubasi tercepat 29.84 jam dan jumlah mortalitas tertinggi $94.66 \%$

\section{UCAPAN TERIMAKASIH}

Kami sampaikan terimakasih kepada Universitas Brawijaya yang telah mendukung dan memberikan kemudahan dalam penelitian ini.

\section{DAFTAR PUSTAKA}

Agaisse, H. \& Lereclus, D. 1995. How does Bacillus thuringiensis produce so much insecticidal crystal protein. Journal of Bacteriology. 177 : 6027-6032.

BP2TP NTB. 2014. Wawancara serangan Spodoptera litura di Desa Setanggor Lombok Tengah. 2014

Busvine, J. R. 1971. A Critical Review of The Techniques for Testing Insecticides. Commonwealth Agricultural Bureaux. London: 345 pp.

De Vos, P., Garrity, GM., Jones, D., Krieg, NR., Ludwig, W., Rainey, F.A., Schleifer, K-H., Whitman, WB. 2009. Bergey's Manual of Systematic Bacteriology: The Firmicutes Springer. Vol. 3

Kenneth, Todar. 2012. Textbook of Bacteriology. University of Wisconsin. Department of Bacteriology.

Lee, M.K., You, T.H., Gould, F.L. et al. 1999. identification of residues in Domain III of Bacillus thuringiensisCryIAc toxin thar affect binding and toxicity Applied and environmental. Microbiology. $65: 4513-4520$

Mandal, S.M.A., B.K. Mishra, and P.R. Mishra. 2003. Efficacy and economics of some biopesticides in managing Helicoverpa armigera (Hubner) on chickpea. Annuals of Plant Protection Sciences 11: 201 203.

Margulis, L., Jorgensen, J, Dolan, S., Kolchinsky, R., Rainey, F., and Shyh-Ching. "The Arthromitus stage of Bacillus cereus: Intestinal symbionts of animals." Proceedings of the National Science AcademyU S A. 1998. Volume 3; 95(3). p. 1236-1241

Rohani, Luh Poni Sri. 1991. Pengendalian Biologis Dengan Jamur. Bahan Pengajaran/Kuliah Pusat Antar Universitas Bidang Ilmu Hayati-ITB.

Tanada, Y. and H.K. Kaya.1993. Insect pathology. Academic Press, San Diego, California. 563p

Untung, K. 1993. Pengantar pengelolaan hama terpadu. Gadjah Mada University press : Yogyakarta 